\title{
ANALYSIS AND UNDERSTANDING OF KEY MARKETING CONCEPTS MARKETING ACTIVITIES ORGANIZED WITHIN THE FOOTWEAR INDUSTRY COMPANIES
}

\author{
Carmen Adina Paştiu ${ }^{1}$
}

\begin{abstract}
Marketing in its hypostasis: optical and economic design, practice science and art, it appears and develops in the context of a competitive economy, as a necessity of business success. These considerations and not only determined us researching its direct steps: business to business, and to identify characteristics of marketing activities undertaken by companies in competitive markets. In this paper we follow, based on research carried out on a sample of 160 statistical units (footwear industry companies in Romania), issues related to understanding the main concepts of marketing and marketing analysis manager mentality.
\end{abstract}

Key words : business to business, marketing activities, marketing analysis manager mentality

JEL:M31, M14

\section{Introduction}

Marketing is often considered as one of the most attractive elements of management. Marketing is a factor with a major contribution to the profitability of firms, and managers need to coordinate marketing efforts with all other aspects of the business in order to be successful

In the context of new challenges being placed on marketing, it is absolutely necessary to master not only the information technology but it needs marketing skills - skills for planning, logistics, creativity - based on a superior understanding of the market environment of its forces, and the need to produce in large values. These are conditions and success of companies in the future survival.

The dominant strategy in business practice in the '90s was reengineering the company level. Large or small companies were set, and new processes were designed to increase productivity. In countries like USA, UK, this strategy has greater scope among firms; it was found that sales fell faster than costs. (Robertson T.S., 1993). It is clear that a reengineering of the company offers multiple benefits but recent studies show that it is mainly short-term shape.

In "The effects of organizational downsizing on product innovations" authors Dougherz D. and Bowman Edward H. state that the company must be accompanied by revitalizing redesign its emphasis on innovation. These two concepts must coexist in the strategic approach to our business.

In our country, the enterprise management strategy is heavily dominated by point, by market strategies, product strategies, pricing, and not least by organizational strategies. In most cases, the general strategy of firms is not considered in line with company's mission and strategic outlook.

The concept of redesign coexists in Romanian light industry enterprises with elements of revitalization, and market growth should indicate ways and provide opportunities for the future. During 1990-2010, in order to put more emphasis on restructuring methods using mainly related to staff reduction, reorganization of the company by splitting into several smaller companies.

Was applied in many management situations based on company profit centers but did not include restructuring the entire business productive.

1 „1 Decembrie 1918” University, Alba Iulia, e-mail: carmenpastiu@yahoo.com 
The central element of the marketing activity in light industry believe that we should rethink as: marketing, marketing

Directions for marketing tasks in the new context meaning would be:

口 Marketing as a cultural system,

- Marketing as a strategy,

a Marketing as a tactics.

Marketers should consider the customer first. Customer shall not be considered the last link of the chain movement of goods.

\section{Survey: Status of implementation of marketing management practice in the Romanian footwear industry \\ Research methodology}

The population studied in this research consists of companies operating in the footwear industry in Romania. The unit of observation in this case was the company that operates in the footwear industry. Survey unit was represented by: Director General, head of marketing or management person in the marketing department. In some cases due to lack of communication was the marketing department with people shopping section.

Marketing research is conducted quantitative research. How to communicate with the unit investigated was based on interviews conducted by mail and e-mail, and the technique used was the interview conducted. Questionnaire was presented to all subjects in the same order and with the same wording. Research was done on a sample of 160 statistical units.

\section{Research objectives}

The overall objective was to identify the current situation on the application of marketing in practice management companies in the footwear industry in Romania.

In Romanian literature there are relatively few studies of marketing throughout the country. Together with existing studies, it is like a new source of information for the organization of marketing, strategic planning for managers interested in global marketing activities and for other researchers, especially the analysis is that the footwear industry

$\mathrm{O}_{1} \quad$ On the application of marketing in the footwear industry enterprises

$\mathrm{O}_{2} \quad$ Analysis understanding of key concepts of marketing activities

$\mathrm{O}_{2.1}$ existing marketing department

$\mathrm{O}_{2.2}$ analysis of the marketing department staff

$\mathrm{O}_{2.3}$ analysis of consultation marketing specialists

$\mathrm{O}_{2.4}$ use of promotional activities;

Hypothesis:

$\mathrm{H}_{01}$ : The most general managers of companies in the footwear industry specialists see no marketing decisions

\section{Interpretation of results}

Using statistical analysis of the results we studied the correlation between different variables established using: software Analyses -IT and Statistics 


\section{$\mathrm{O}_{2.1} \quad$ Existing marketing department}

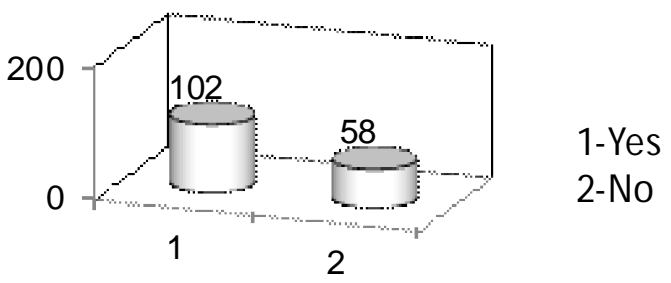

Fig.no.1 - Existing marketing department

It can be seen that $65 \%$ of the investigated companies -existing marketing department.

A) The analysis statistical correlation between the production system and the existence of the marketing department (Pearson test, probability 95\%)

It is noted that between the existence of the company marketing department and production systems are closely related.

Statistics confirm this link, which is presumed to exist in economics.

The correlation coefficient is 0,87 and $t=0,3258$

We also performed Spearman test (has the value 1.00) to strengthen the previous results as if a close link between this variable takes values close to 1 .

Dependency between two variables is given in the table for which coefficients were calculated (tab.no.1)

Table no. 1

Existing marketing department/ Production system

\begin{tabular}{||l|l|c|l|l|c||}
\hline \hline & & & $\begin{array}{l}\text { Production } \\
\text { system }\end{array}$ & & \\
\hline & & Lohn & Combined & Full bussines & Total \\
\hline & Yes & 61 & 11 & 30 & 102 \\
\hline $\begin{array}{l}\text { Existing } \\
\text { department }\end{array}$ & No & 24 & 29 & 05 & 58 \\
\hline & Total & 85 & 40 & 35 & $\mathbf{1 6 0}$ \\
\hline
\end{tabular}

$38 \%$ of enterprises have lohn marketing department and $18 \%$ marketing department and factory production system- full business

B) The analysis statistical correlation between the firm's legal status and existence of the marketing department

The connection appears between existing company marketing department and the legal status of the company is strong. So we can discuss the existence of the marketing department in the context of analyzing the legal status of company.

Coefficient Pearson 0,94. Correlation is significance level $\mathrm{p}<=0,05(0.01$ is also used depending on the importance) and for these variables $\mathrm{p}=0,049$.

The level of significance is the probability for which values of $p$ are declared significant $p=$ 0.1300 may take 1 or 2 tailed alternative hypothesis according to the set. In this case $\mathrm{p}$ is calculated using $\mathrm{t}$ test approximation 


$$
\begin{array}{r|rr}
\mathbf{n} & 3 \\
\begin{array}{r}
\text { R statistic } \\
\mathbf{9 5 \%} \mathbf{C I}
\end{array} & 0,94 & \\
& & \text {-to - }
\end{array}
$$

2-tailed $\mathbf{p} \mid \quad 0,2219 \quad$ (t approximation)

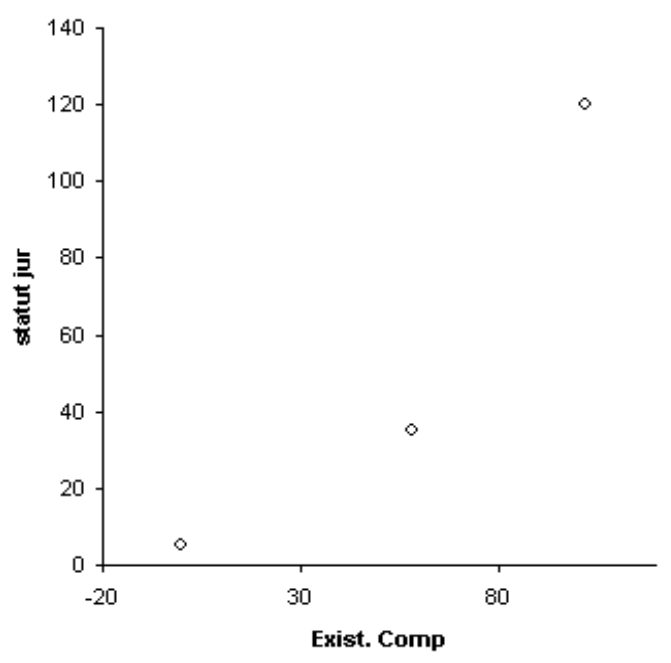

Fig.no2 - Existing marketing department / Legal status

Table no. 2

Existing marketing department / Legal status

\begin{tabular}{|l|l|l|l|l|l||}
\hline & & & \multicolumn{1}{l|}{$\begin{array}{l}\text { Legal } \\
\text { status }\end{array}$} & \multicolumn{2}{|l|}{} \\
\hline & & SRL & SA & Other & Total \\
\hline Existing marketing & Yes & 93 & 6 & 3 & 102 \\
\hline departament & No & 27 & 29 & 2 & 58 \\
\hline & Total & 120 & 35 & 5 & $\mathbf{1 6 0}$ \\
\hline
\end{tabular}

It can be seen by analyzing data from tab.no.2: SRL entreprises their marketing department $-77,5 \%$ and SA $17 \%$.

$O_{2.2}$ Staff analysis of the marketing department

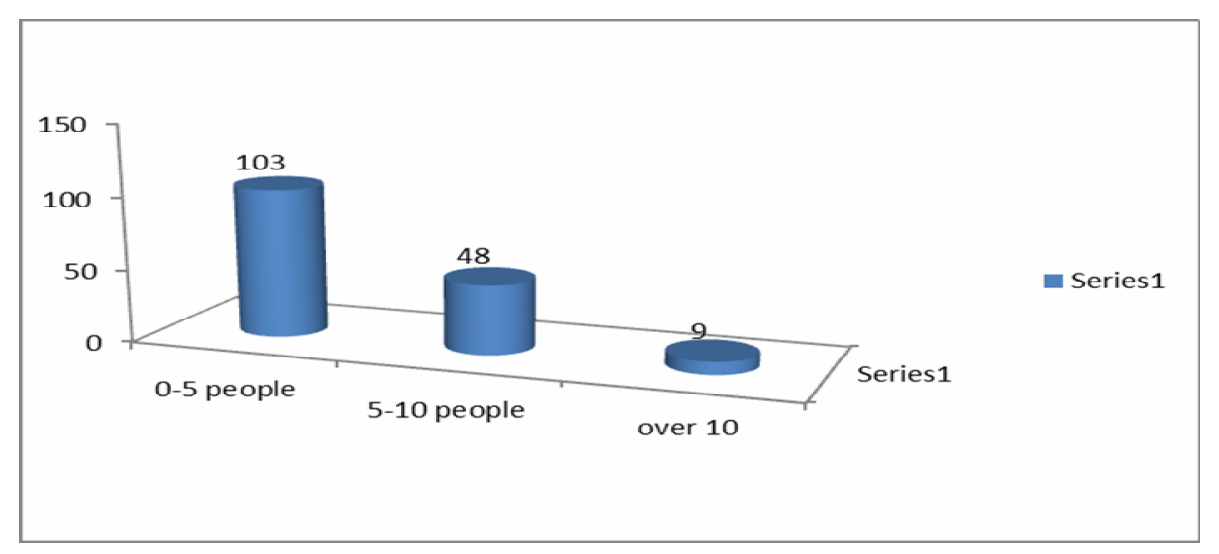

Fig.no.3 - Staff marketing department 
1 betwen $0-5$ people $25-10$ people 3 over 10

It may be noted that generally the marketing department and working up to 5 persons in cases of more than 5 persons and those 10 are counted and those that deal with distribution and sales.( $\mathrm{r}$ is 0.99 )

The relationship between the existence of the marketing department and staffing of the department is close. There is a strong statistical link. Economic dependence of the variables is clear.

A) The analysis correlation between the number of staff and turnover of the company

From an economic think it would be a firm link between financial capacity and number of employees of both the marketing department and the firm generally given about the financial potential of staffing. Correlation is significant $\mathrm{p}<, 05000 \mathrm{~N}=4$

The correlation coefficient is $0,334, \mathrm{p}=, 666$.

Statistical analysis of results shows that the two variables are not in a relationship but the systematic rejection coefficient which does not even reach the threshold of 0.5 points out that we must not establish links between these variables. From these variables statistically have no correlation.

B) The analysis correlation between the number of staff and production systems. Of economically between these two variables should be linked

Correlation is significant $\mathrm{p}<, 05000, \mathrm{~N}=4$. The correlation coefficient is $0,934, \mathrm{p}=, 066$.

It is noted that the link is very close correlation coefficient value approaching the maximum value. Also value the significance level is very good. We believe that between the two variables is a strong correlation, and this can be used in other future studies

Table no.4

No. of people / Product system

\begin{tabular}{||l|l|l|l|l|c||}
\hline & & & $\begin{array}{l}\text { Product } \\
\text { system }\end{array}$ & \\
\hline & & Lohn & Combined & $\begin{array}{l}\text { Full } \\
\text { bussines }\end{array}$ & \\
\hline & $0-5$ & 71 & 20 & 12 & 103 \\
\hline No. people & $5-10$ & 14 & 19 & 15 & 48 \\
\hline & 10 & 0 & 1 & 8 & 9 \\
\hline & & 85 & 40 & 35 & 160 \\
\hline
\end{tabular}

\section{$\mathrm{O}_{23}$ The analysis marketing consulting companies specialists}

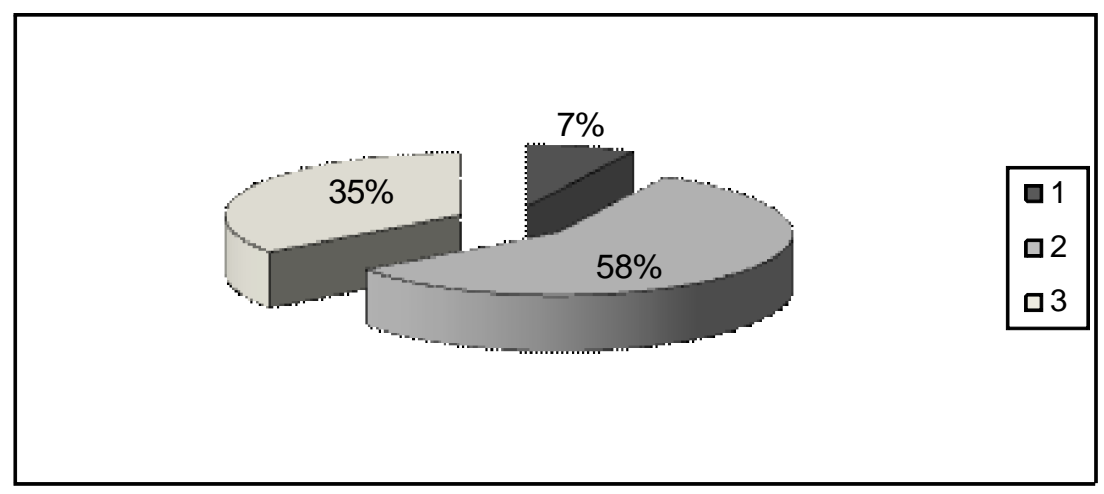

Fig.no.4 - Consulting companies specialists

1- never, 2- sometime, 3- alweys

The analysis of the consultation question on people working in the marketing department is generally observed that they are consulted where there marketing department 
If the size of the questionnaire we would be allowed would be interesting to see to what extent they see higher management level, operational level marketing department staff in decision making

- $\quad \mathrm{H}_{01}$ :Most general managers of companies in the footwear industry specialists see no marketing decisions to deny

A) The analysis statistical correlation between consulting marketing specialists and legal status of companies

Of economically is assumed that there is link

Correlation is significant $\mathrm{p}<, 05000$

$\mathrm{N}=4$ The correlation coefficient is $0,301, \mathrm{p}=, 699$

It can be seen that the two variables there is no statistical relationship, the correlation is not taken into account

B) The analysis statistical correlation between external expertise marketing and production systems of firms

Correlation is significant $\mathrm{p}<, 05000, \mathrm{~N}=4$. Correlation coefficient $=0,061, \mathrm{p}=, 939$

There is no statistical connection and there is no systematic relationship between them.

\section{$O_{2.4}$ Analyzing the use of advertising to promote products}

Companies use advertising and publicity as a means of promoting $75 \%$ products. Among the most widely used advertising media mention: newspapers, magazines and participation in fairs and exhibitions

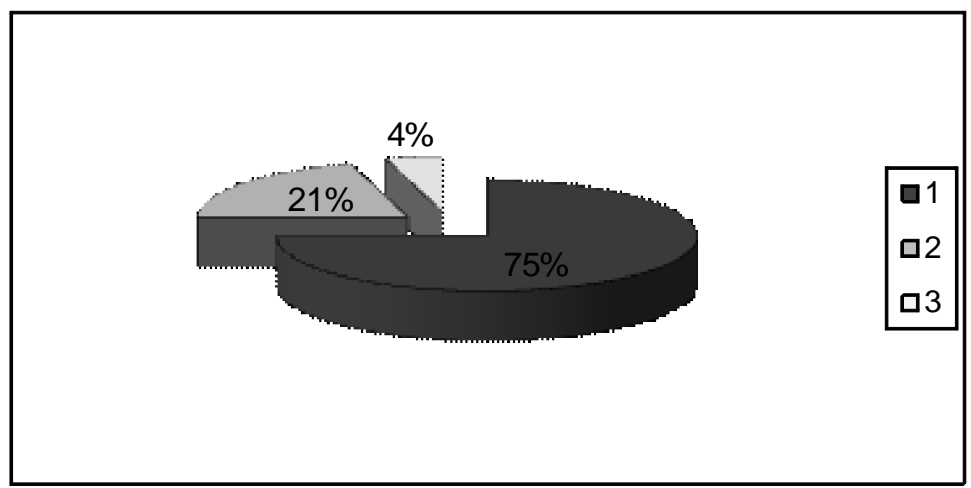

Fig.no.5 - Use of advertising to promote products

1- Yes 2- No 3-I do not know

There are several shoe industry fairs are very important and present a considerable number of companies. From March to May are held in Constanta-Neptun fair since the 1980s, during the autumn in Bucharest and Iasi in February

To promote the type of consumer behavior that targeted "to buy Romanian products' campaigns are necessary, correct and complete information. Should be given more attention to packaging. It is very important to participate in national and international fairs and exhibitions. ASOEXPO is the association of fairs and exhibitions organizer in Romania.

Another important aspect is the development of stores even if they are inside the company. There are a number of companies due to the production system have not found it necessary to have its own retail store.

A) The analysis statistical correlation between the use of creative marketing and production systems of firms 
Correlation is significant $\mathrm{p}<, 05000 \mathrm{~N}=4$. Correlation coefficient $=0,933, \mathrm{p}=, 067$

The correlation coefficient indicates a significant connection between the two variables

B)The analysis statistical correlation between use advertising and turnover

Correlation is significant $\mathrm{p}<, 05000, \mathrm{~N}=4$

Correlation coefficient $=0,138, \mathrm{p}=, 862$

Correlation is not significant. It is very interesting that is not dependent on advertising using turnover variable gives information about the company's financial strength. If I had this information I was tempted to say that firms with high incomes spend a great amount of advertising. Must take into account the particularities of traditional light industry and customer situation

\section{Conclusions}

Although a sectorial approach, consider that many research results are valid for the whole Romanian economy, as some are priority sector. All these problems necessarily require reassessment of the marketing companies operate and review ways in which marketing can be introduced and accepted as business philosophy

Improved marketing is a sure way to success, to win and consolidate a position favorable to companies operating in the leather and footwear sector. In the new conditions of increasing competitiveness and the openings offered by European markets, companies need updated concepts, on the level where you have to organize marketing activities in order to successfully adapt to changing business.

Factors of influence and conditioning that are imposed for shoe industry and the underlying medium-term objectives are:

- Increased competition from developing countries holding raw materials;

- Material and energy costs high compared to similar industries in developed countries;

- Interrupt on horizontal cooperation links between economic,

- Limited opportunities to ensure indigenous raw materials;

- Mutations in the structure and requirements of foreign markets;

- Domestic and foreign situation with direct impact on industry;

- Capacity to adapt quickly (flexibility) to global trends (such as line mode).

Lohn processing system is useful only in the short term (provides introduction of new technologies, application performance management, providing new equipment) but the medium and long term is harmful (limited access to new market segments, maintain a low profit and prevent normal development of the industry) . Diagnosis performed revealed that several issues and sub footwear manufacturing industry is competitive.

We recall the following strengths:

- high degree of privatization;

- high level of competitiveness;

- highly skilled labor;

- tradition.

Weaknesses:

- the existing technological gap with developed countries in the tanning of leather ;

- the standard of living and purchasing power ;

- Insufficient financial resources to modernize production capacity and develop new capacities viable;

- the technological gap with developed countries. 


\section{References}

1. Achim M.I., Dragolea L., 2008. The Paradigm Of The Managerial Position, Annales Universitatis Apulensis Series Oeconomica, 10(2), pp. 36

2. Abrudan, I.,Lobontiu, G., 2003. IMM-urile şi managementul lor specific, Dacia Publishing House, Cluj- Napoca

3. Anghel, D., Petrescu, E., 2002. Business to business marketing, Uranus Publishing House, Bucharest

4. Bacali, L.,1999. Promovarea marketingului în managementul românesc, Economică Publishing House, Bucharest,1999

5. Barney J.B., 1991. Firm resources and sustained competitive advantage, Journal of Management, No.17, pp. 99-120

6. Birley, S., 1982. Corporate strategy and the small firm, Journal of General, Management, Vol.8, No. 2, pp. 82

7. Dragolea L., Cotirlea D., 2009. Benchmarking - a valid strategy for the long term?, Annales Universitatis Apulensis Series Oeconomica, 11(2), pp. 814

8. Paştiu, C., 2005. Direcții de acțiune strategice pentru firmele din România - pe exemplul industriei de încălțăminte, Tribuna Economică Review, No. 35, pp.53

9. Paştiu, C., 2011.Marketing in industria usoara, Editura Altip, Alba Iulia, pp 170-200

10. Robertson T.S., 1993. How to reduce market penetration cycle times, Sloan Management Review, vol 35, pp. 87-96 